\title{
Генезис та еволюційні трансформації економічної культури: соціально- філософський аналіз
}

\author{
Рудан Н. С., Південноукраїнський національний педагогічний університет імені К. Д. Ушинського
}

Вивчено генезис та еволюційні трансформації економічної культури під кутом зору соціальної філософiї, що дало можливість отримати системну інформацію про перетворення економічної культури, розвиток економічної культури в сучасному суспільстві. Уточнено сучасне розуміння значення економічної культури як «проекції» культури (в іiї широкому розумінні) на сферу соціально-економічних відносин. Досліджено модель «економічної людини» - «homo economicus», що полягає у: раціоналізмі, егоїстичному індивідуалізмі, бажанні до насолоди та прагненні уникнути страждань скрізь, де це тільки можливо. Затверджується взаємозв'язок та взаємодія економічних і соціальних процесів як необхідна складова економічної стабільності суспільства. Встановлено значення трансформації економічних систем для фактичного благополуччя сучасної людини, що полягає в його економічній поведінці. Виявлено смисловий зміст раціональної поведінки, необхідної для успішного розвитку сучасного українського суспільства. Показано значення економічної культури для успішного розвитку сучасного суспільства, що полягає у: з'єднанні економічного і соціального середовища в єдине ціле; економічній поведінці людини; втіленні духовних цінностей та інтересів у матерію дій.

Ключові слова: культура; економічна людина; економічна система; економічна поведінка; трансформація економічних систем

\section{Genesis and evolutionary transformations of economic culture: social- philosophical analysis}

\section{Rudan N. S., K. D. Ushynsky South Ukrainian National Pedagogical University}

The Genesis and evolutionary transformations of economic culture are studied in terms of social philosophy, which made it possible to obtain systematic information about the transformations of economic culture, the development of economic culture in modern society. The modern understanding of the importance of economic culture as a «projection» of culture (in its broad sense) on the sphere of social and economic relations is specified.

The model of «economical person» - «homo economicus», consisting in: rationalism, selfish individualism, desire to enjoy and desire to avoid suffering wherever possible, is investigated. We consider the behavior of the «economical person» as a kind of paradigm of rational action based on the system planning not only of economic development, but also the creation of an ideal model of economic mode of action. It should be borne in mind that the model of the economical person was created not for the study of man, but for the study of economic life. And it is successful economic life that will lead to the public good, which will be based on enjoyment from rational economic behavior.

Therefore, the model of «economical person» includes such parameters as: the unlimited needs of the subject and the presence of a set of preferences and restrictions. And the result of preferences and restrictions is based on the action taken in a situation of limited resources and having the character of choice in accordance with subjective preferences. Thus, economic human behavior in the selection of goods according to their preferences acts very prudent to constantly maximize the difference between benefits and costs, always choosing the most optimal variant of actions affecting socioeconomic condition of the society.

Interrelation and interaction of economic and social processes as a necessary component of economic stability of society is approved. The importance of the transformation of economic systems for the actual well-being of modern man is established, consisting in its economic behavior.

The semantic content of rational behavior necessary for the successful development of modern Ukrainian society is revealed. The article shows the importance of economic culture for the successful development of modern society, which consists in: connecting the economic and social environment into a single whole; economic behavior of man; the embodiment of spiritual values and interests in the matter of action.

Keywords: culture; economic person; economic system; economic behavior; transformation of economic systems 


\title{
Генезис и эволюционные трансформации экономической культуры: социально-философский анализ
}

\author{
Рудан Н. С., Пивдэнноукраинский национальный педагогический університет имени К. Д. \\ Ушинского
}

Изучено генезис и эволюционные трансформации экономической культуры под углом зрения социальной философии, что дало возможность получить системную информацию о преобразованиях экономической культуры, развитии экономической культуры в современном обществе. Уточнено современное понимание значения экономической культуры как «проекции» культуры (в ее широком понимании) на сферу социально-экономических отношений. Исследована модель «экономического человека» - «homo economicus», заключающаяся в: рационализме, эгоистическом индивидуализме, желании к наслаждению и стремлении избежать страданий везде, где это только возможно. Утверждается взаимосвязь и взаимодействие экономических и социальных процессов как необходимая составляющая экономической стабильности общества. Установлено значение трансформации экономических систем для фактического благополучия современного человека, заключающееся в его экономическом поведении. Выявлено смысловое содержание рационального поведения, необходимого для успешного развития современного украинского общества. Показано значение экономической культуры для успешного развития современного общества, заключающееся в: соединении экономической и социальной среды в единое целое; экономическом поведении человека; воплощении духовных ценностей и интересов в материю действий.

Ключевые слова: культура; экономический человек; экономическая система; экономическое поведение; трансформация экономических систем

\section{Постановка проблеми.}

$\mathrm{E}$ кономічна культура містить базові елементи економічні цінності і норми, сформовані та найпоширеніші в даному суспільстві економічні стереотипи і міфологеми, ідеї, концепції та переконання, економічні традиції, а також установки та орієнтації людей щодо існуючої економічної системи в цілому, визначених важливих «правил гри» i принципів взаємовідносин індивіда та економічних інститутів. Ці компоненти обумовлені соціально-економічними, національно-культурними, суспільно-історичними та іншими факторами, які характеризуються усталеністю, живучістю та стійкістю і не піддаються швидким змінам, навіть у періоди глибоких трансформацій у суспільному житті. Зміни в економічній та інших сферах суспільства створюють умови для перетворення спільної діяльності людей. Тому деякі економічні норми 3 часом перестають задовольняти потреби суб'єктів економічного процесу, стають незручними та марними. Ба більше, застарілі норми є гальмом для подальшого розвитку економічної системи. Це заважає розвитку суспільства та успішності людини, тому людство у сучасності спрямовує свою діяльність на перетворення застарілих норм та цінностей, щоб привести їх у відповідність із новими умовами життя. Особливо цінним, як нам здається, в даному контексті буде саме соціально-філософський аналіз сутності та специфіки еволюційних трансформацій економічної культури.

Актуальність статті полягає в необхідності вивчення трансформацій економічної культури 3 точки зору соціальної філософії, що передба- чає розуміння розвитку не тільки людини економічної, але й ціннісно-нормативної системи суспільства як ареалу проживання такої людини, специфіку розуміння економічної культури як соціальної системи, дослідження особливостей і характеристик сучасного економічного життя.

Мета статті: визначити основні чинники та особливості генезису і еволюційних трансформацій економічної культури в площині соціальної філософії.

\section{Аналіз публікацій та досліджень.}

Культура - винятково різноманітне поняття. Цей науковий термін з' явився у Древньому Римі, де слово «cultura» позначало оброблення землі, виховання, утворення. Римський письменник Катон Старший написав трактат про землеробство, вживши слово «агрикультура» [11]. Мова в ньому йшла про догляд за ділянкою землі. Обробіток грунту неможливий без особливого душевного настрою. А без граничного інтересу до ділянки не буде і культури. Потім слово «культура» відривається від земного грунту і метафорично співвідноситься 3 розумністю. Так, Марк Тулій Цицерон уже мав на увазі не землю, а духовність, ведучи мову про необхідність розвитку культури душі і духу [12]. Увійшовши в буденну людську мову, в ході частого вживання це слово втратило свій первісний зміст і стало позначати найрізноманітніші сторони людської поведінки, а також видів діяльності.

В епоху Античності відбувалося осмислення господарської діяльності людини крізь призму створеної ним речі, яка якісно відрізняється від іiі творця-людини. На цю сторону справи в 
господарському житті і діяльності людини звертали велику увагу Гесіод і Фукідід, Ксенофонт і Демокріт, Посидоній, Полібій та інші античні історики й філософи. Адже людина, як вважав Демокріт, відрізняється від тварин головним чином створеною ним «другою природою», тобто штучними умовами життя. Через кілька століть, вже на заході Античності, Августин відзначає, що речі можуть і повинні бути оцінені з точки зору їх місця та ролі в універсумі, їх користі для людини. Це було кроком вперед у переосмисленні моделі світу, властивій міфологічному мисленню, а саме: визнання тотожності та злитості одухотвореного (людини) і неживого (речі). Річ у міфологічному сприйнятті «має буття і тримає його при собі», річ своїм «життям», своїм «характером» і т. д. продовжує і доповнює життя, характер, інші властивості і якості людини. В близькосхідній історичній думці - сучасниці античної - також спостерігається активний інтерес до господарського життя.

В епоху Середньовіччя економічна культура, як і суспільно-державне життя в цілому, пронизувалася релігійно-теоцентричним світоглядом та інтерпретувалася в дусі догматів Святого Писання. Економічна культура ще не була структурована як самостійна, автономна система.

Сучасне розуміння значення економічної культури починається, на мою думку, зі створення моделі «економічної людини», яка, хоча і в не дуже виразному вигляді, була присутня в класичній політичній економіці в А. Сміта, Д. Рікардо, Дж. Ст. Мілля та багатьох інших. Але в особливо ясному, експлікованому вигляді вона передбачається в сучасній економічній теорії, перш за все в домінуючому неокласичному напрямку $[9 ; 10 ; 13 ; 14 ; 16 ; 17 ; 18 ; 19 ; 20 ; 22$; 24].

Зазначу, що соціально-філософський погляд на економічну культуру припускає, що вона пов'язана не тільки зі сферою економіки, але водночас і зі сферою соціальних відносин, почавши складатися уже в кінці XX століття. Було показано, що в аналізі економічної культури повинні враховуватися два середовища - економічне та соціальне, які з'єднані в єдине ціле, оскільки соціальні відносини завжди пронизані економічними [4, с. 314].

А вже в XXI столітті А. С. Карміним був виділений ряд функцій економічної культури в економічній системі сучасного суспільства 3 прицілом на соціально-філософський контекст вивчення [2].

Необхідно також виділити дослідження Ауреліо Печчеї, що виділяють загальнолюдські цінності, які позначаються на економіці, стосуються найбільш загальних зв'язків між людьми. Вчений зараховує до них гуманізм, соціальну справедливість, свободу, неприйняття насильства в будь-яких його формах, цінність прогресивного розвитку, а до числа цінностей вищого порядку, від яких залежить саме існування людського роду, - здатність зберігати накопичену культуру [6, c. 210]. Дані ідеї значною мірою вплинули на мою роботу.

Виклад основного матеріалу.

Якщо для феномена культури фундаментальним параметром є аксіологія в особі поваги традиції, то такі факти, як збільшення ролі планування, говорять про зниження ступеня присутності в площині економіки мотивів свободи, бо попередньо складений план надалі буде «лещатами» для свободи. Поділ власника, організатора, робочого і одержувача доходу, наприклад інвестора, говорить про «перекрокування» через існуючі в сфері економіки традиції. Це перші штрихи специфіки економічної культури, які очевидно промальовуються. Продовжимо їх виявлення, розглядаючи підстави феномена економіки.

Однією 3 важливих специфічних рис економічних теорій $є$ використання в них антропологічних та культурологічних припущень. При аналізі структури економічного знання виявляється, що однією 3 його фундаментальних передумов $є$ «модель людини», яка зазвичай називається «економічна людина» - «homo economicus» [5]. Це найвищою мірою проблематичний людський тип, із яким навряд чи можна зустрітися в звичайному житті. Homo economicus - наскрізь раціональний тип. Це або споживач, що ретельно розраховує перед кожною покупкою вигоду і перед прийняттям рішення порівнює між собою безліч цін, або підприємець, інформований у всіх деталях про ситуацію на ринку, який вибирає 3 усіх рішень найбільш ефективне для себе.

Модель «економічної людини» виконує в економічній науці роль, яку можна порівняти 3 такими базисними теоретичними схемами в природничих науках, як, наприклад, генетична модель спадковості в біології. Однак, іï когнітивний статус суттєво інший. Справа в тому, що ця модель створювалася не для вивчення людини, а для дослідження економічного життя. Це антропологічна передумова, а не антропологічна теорія, не результат спеціального вивчення людини.

Тепер слід розглянути витоки та еволюцію самої ідеї і моделі «економічної людини». Необхідність цього кроку стосовно цілей даного дослідження обумовлена тим, що він дозволяє 
провести паралелі і встановити схожі моменти між генезисом ідеї «економічної людини» та генезисом феномена культури. Іншими словами, тут мова йде про явну точку дотику областей економіки і культури, навколо якої формується певна «міждисциплінарна» область існування економічної культури. В результаті проведення даних паралелей 3'являється можливість виявити ступінь, характер і механізми інсинуації раціональних, а, що розуміється, і культурологічних складових на площину економічних процесів.

Отже, першим і широко відомим джерелом даної ідеї є уявлення про те, що в економічному житті люди діють як «егоїстичні індивіди», вмотивовані лише власним інтересом. Це уявлення поділяли багато економістів XVIII ст., зокрема, воно тісно пов'язане зі вченням Адама Сміта [7]. Однак, ринок гармонізує егоїстичні інтереси безлічі людей. Так, кожен виробник, прагнучи до власної вигоди, виробляє такі товари, які мають попит і вище цінуються на ринку. Але, оскільки цього ж хочуть і інші виробники, таких товарів буде вироблено багато, вони стануть не настільки рідкісними, і ціна на них буде знижуватися. Таким чином, прагнучи до своєї вигоди, виробники вступають один з одним у конкуренцію, виробляють продукти, потрібні споживачам і не можуть довільно завищувати їх ціну. У результаті, як писав А. Сміт, «невидима рука» ринку веде виробників до суспільного блага.

Інший, менш очевидний виток моделі «економічної людини» йде від утилітаристської етики, насамперед від I. Бентама і його «моральної арифметики» [1]. I. Бентам вважав головні етичні категорії «добро», «благо», «зло» занадто розмитими. Замість них він увів два інших основних вектора - насолоди і страждання. Людина завжди прагне першого і намагається уникнути другого. Але головним було те, що I. Бентам приписував людині здатність кількісного вимірювання різних насолод і страждань, ї порівняння i підрахунку їх суми як результату певної дії. Для економічної науки ідея можливості оцінки і порівняння бажань та потреб була дуже важлива, тому що це, по суті, є прямою вказівкою на присутність у підставах феномена економіки раціонально-антропологічних структур і механізмів.

Роботи I. Бентама допомогли зробити «маржиналістську революцію» в економічній науці у 1870-их роках. У їх теоріях граничної корисності вперше в достатньо чіткому вигляді i була експлікована модель економічної людини як «раціонального максимізатора корисності». Ця модель потім закріпилася в «основній течії економічної теорії.
У рамках цього домінуючого напряму економічної науки в модель «економічної людини» входять такі параметри:

- необмеженість потреб суб'єкта;

- наявність сукупності переваг і обмежень: дія завжди відбувається в ситуації обмежених ресурсів і носить характер вибору у відповідності із суб' єктивними вподобаннями. Тут слід особливо звернути увагу на те, що сукупність переваг і обмежень може розглядатися як врівноважена система двох величин, однією 3 яких $\epsilon$ переваги, іншою - обмеження. Причому дана система має ті ж раціональні підстави, що і феномен культури.

Це ще раз свідчить про те, що висунуте в даному дисертаційному дослідженні припущення про наявність спільних точок дотику і схожих підставах економіки і культури не є безпідставним.

«Економічна людина» у своїй поведінці, виборі благ у відповідності зі своїми вподобаннями діє гранично ощадливо, вона постійно максимізує різницю між вигодами і витратами, завжди обираючи найбільш оптимальний для себе варіант дії. Потрібно зазначити, що таке розуміння раціональності відрізняється від розуміння раціональної дії на рівні здорового глузду. «Раціональна максимізація» також більш жорстка вимога порівняно 3 відомим трактуванням «раціонального дії» у М. Вебера [23]. М. Вебер розрізняв два іiі види: «ціле-раціональну дію» та «ціннісно-раціональну дію». Останнє, в порівнянні 3 раціональністю поведінки «економічної людини», взагалі навряд чи можна зарахувати до раціональної поведінки. Але і перше з цієї точки зору являє собою слабкий вид раціональності. По-перше, у М. Вебера мова йде лише про відповідність цілей і засобів дії, і в явному вигляді не передбачається момент максимізації корисності. По-друге, його ціле-раціональна дія як дія «соціальна» передбачає «орієнтацію на іншого». А раціональність «економічної людини» передбачає, що вона діє у відповідності з власними інтересами, та іiі рішення визначаються тільки їі власними уподобаннями, а інтереси і цілі інших людей ій байдужі.

Враховуючи настільки сильне трактування раціональності, яка закладена в обговорювану модель, можна розглядати поведінку «економічної людини» як своєрідну парадигму раціонального дії. Однак, переконливість цієї тези залежить від відповіді на ряд запитань. Насамперед, ця модель явно суперечить цілісному знанню про людину та іiі поведінку. Крім того, модель раціональної економічної поведінки, як зазначалося, склалася не в результаті спеціального 
вивчення людини та їі поведінки, вона вводилась як свого роду апріорна антропологічна передумова для потреб побудови економічної теорії. Так, Дж. Ст. Мілль вважав, що поведінка «економічної людини» - це абстрактний зріз людської поведінки. Дії людей наближаються до цієї абстрактної картини, але лише у сфері економічного життя [21]. Л. фон Мізес доводив, що можна створити апріорну теорію людської діяльності - «праксеологію», частиною якої $є$ чиста економічна теорія. Модель раціональної максимізуючої поведінки виводиться тут апріорно [3, с. 33-42]. Вона реальна для досконалого ринку та іiі неможливо емпірично фальсифікувати, оскільки якщо вона не працює, то це означає, що ринок недосконалий, що якісь фактори і сили його регулюють і спотворюють.

Найбільш відома й досі поширена позиція М. Фрідмена, запропонована ним в есе «Методологія позитивної економічної науки» [8]. М. Фрідмен вважає, що гідність передумов економічної теорії, в першу чергу передумови «економічної людини», полягає не в їх «реалістичності», а в тому, що побудовані на їх основі теорії успішно пояснюють і передбачають реальні явища. М. Фрідмен дотримується інструменталістської епістемологічної позиції. Тут «економічна людина» - це «ідеальний тип», «ідеальна модель», яку можна безпосередньо проектувати на реальне поводження. Але ця не дуже реалістична модель виправдана тим, що породжує хороші теорії.

Втім, далеко не всі західні економісти розглядали ринок як панацею. Тут в якості прикладу можна навести Дж. Гелбрейта - одного 3 найвидатніших економістів XX століття [15].

Дж. Гелбрейт є одним із видатних представників інституціоналізму. У своїх наукових працях він досліджував тенденції укрупнення промислового виробництва, які призвели до утворення гігантських корпорацій і акціонерних товариств. Дж. Гелбрейт показував, що корпорації досягають найвищих виробничих успіхів завдяки використанню новітньої техніки і технологій, приходу до керівництва підприємствами так званої техноструктури - технічних фахівців-адміністраторів. Із цим пов'язане посилення планування господарського розвитку, яке, на думку Дж.Гелбрейта, йде на зміну ринкових відносин. У результаті в суспільстві складаються дві системи - «ринкова система» (охоплює переважно дрібні господарства) i «плануюча система», куди входять корпорації, які взаємодіють 3 державою.

Оскільки, як показали попередні кроки дослідження, економічна культура являє собою досить складний феномен інтегративного ха- рактеру, який, по-перше, виражається у зчленуванні, зіткненні і спаяності феноменів культури та економіки, по-друге, виражається в тому, що функціональні прояви економічної культури кореняться в різних соціально-антропологічних площинах, з одного боку, вона задає парадигму і спосіб дії індивіда в умовах ринкового або якого-небудь ще економічно орієнтованого суспільства, з іншого боку, вона допомагає зовнішньому стосовно даного індивіда соціальнму контексту, тобто суспільству, розуміти i оцінювати дії цього індивіда та співвідносити його економічну активність із закладеними в 11 структурі аксіологічними установками (в цій же соціальній площині) і закладеними в даній площині еталонами поведінки.

Отже, феномен економічної культури є тим місцем у координатах соціальної сфери, де відбувається інтеграція взаємних економічних претензій та інтересів індивіда і зовнішнього йому соціального контексту. Доречно припустити та очікувати, що, якщо будуть осмислені механізми конституювання і функціонування феномена економічної культури, будуть отримані додаткові важелі управління економічними і соціальними процесами, що дасть певні переваги в досягненні економічної стабілізації. Це ще раз підкреслює актуальність вивчення феномена економічної культури стосовно сучасних реалій розвитку українського суспільства та обгрунтовує необхідність даного вивчення.

Якщо культура представлена у багатьох сферах - у сфері мистецтва, науки, політики, права, релігії, моралі та економіки, то, говорячи про економічну культуру, маються на увазі ті традиції, звички, усталені норми поведінки, які реалізуються у сфері економіки і пов'язані 3 економічною діяльністю людей.

Проте економічна культура пов'язана не тільки зі сферою економіки, але водночас і зі сферою соціальних відносин. 3 одного боку, звичну економічну поведінку люди реалізують на різних ринках - на ринку товарів і послуг, на ринку праці, на ринку фінансів. Ринки та відносини на них - це те середовище, в межах якого функціонують люди, які є суб'єктами економіки і одночасно носіями економічної культури. В економічній культурі два середовища економічне і соціальне - 3’єднані в єдине ціле, оскільки соціальні відносини завжди пронизані економічними [4, с. 314].

У той же час необхідно відзначити, що при всіх особливостях економічних культур різних країн, скрізь зберігаються одні й ті ж структурні закономірності. Так, економічна культура - це свого роду посередник між комплексом політико-правових, економічних та інших умов тієї чи 
іншої країни і економічною поведінкою суб'єктів економіки. Економічна культура втілює духовні цінності та інтереси в матерію дій: у виробництво товарів і послуг, фінансові операції, торгові угоди, отримання кредиту, виплату податків, упровадження нових технологій і так далі. Саме роль економічної культури в розвитку економіки значна. Більше того, це сумарний результат дій мільйонів людей, які регулюються як зовнішніми інституційними умовами їх діяльності, так і рисами економічної культури самих людей.

Розвиток національних економічних систем обумовив появу комплексу особливих проблем і низки відповідних економічних теорій, які можуть бути об'єднані в даний час у теорію трансформації. Її становлення пов'язане з виникненням ідей економічного будівництва суспільства.

Термін «трансформація» (лат. transformatio) означає перетворення, перетворювання, видозмінювання. Отже, економічна трансформація пов'язана зі зміною економічної системи, але такою зміною системи, при якій відбувається іiі якісне переродження, розвиток. В економічній літературі цей термін часто використовують нарівні 3 поняттями: «період реформування», «перехідний період» або як синонім категорії «розвиток».

Трансформація економічних систем у пе- рехідний період передбачає рух до деякого заданого ідеального образу - моделі системи. Неминучість відповідних перетворень економіки видається наслідком загальних закономірностей розвитку суспільства, виробництва. Але перехід системи в новий якісний стан - складова частина безперервного процесу іiї якісного переродження.

Отже, розглядаючи місце та значення економічної культури, було встановлено, що, якщо вдатися до умовної схеми, яка протиставляє економіку і культуру, то економічна культура зі своїм місцем та змістом буде виглядати як така, що тяжіє більше до полюса культури, ніж до полюса економіки.

\section{Висновок.}

Підводячи підсумки нашого дослідження, можна зробити висновок, що економічна культура - це «проекція» культури (в їі широкому розумінні) на сферу соціально-економічних відносин. Саме «проекція», а не частина загальної культури, оскільки у сфері економіки і пов'язаних із нею соціально-економічних відносин працює вся культура: усі іiі елементи так чи інакше проявляються, функціонують тут. Одним із головних завдань сучасного українського суспільства $є$ розуміння сутності та специфіки розвитку економічної культури, іiі трансформацій у глобалізованому світі.

\section{БІБІЛІОГРАФІЧНІ ПОСИЛАННЯ}

1. Бентам И. Введение в основания нравственности и законодательства / И. Бентам. - М.: РОССПЭН, 1998. $415 \mathrm{c}$.

2. Кармин А. С. Философия культуры в информационном обществе: проблемы и перспективы / А. С. Кармин // Вопросы философии. - 2006. - № 2. - С. 52-61.

3. Мизес Л. Человеческая деятельность: Трактат по экономической теории / Л. Мизес. - Челябинск: Социум, 2005. -878 c.

4. Милгром П. Экономика, организация и менеджмент / П. Милгром, Д. Робертс. - СпБ.: Экономическая школа, 1999. - Т. 1. - 472 с.

5. Петинова О. Б. Экономический человек: опыт социально-философской экспликации / О. Б. Петинова. Одесса: Печатный дом, 2016. - 336 с.

6. Печчеи А. Человеческие качества / А. Печчеи. М.: Прогресс, 1985. 312 с.

7. Смит А. Исследование о природе и причинах богатства народов / А. Смит. - М.: Эксмо, 2007.960 с.

8. Фридмен М. Методология позитивной экономической науки/ М. Фридмен // THESIS: Теория и история экономических и социальных институтов и систем. - 1994. - №4. - С. 20-52.

9. Attick D. Homo Economicus at School: Neoliberal Education and Teacher as Economic Being / D. Attick // Educational Studies: Journal of the American Educational Studies Association. - 2017. - № 53 (1). - P. 37-48.

10. Brecher B. The Family and Neoliberalism: Time to Revive a Critique / B. Brecher // Ethics and Social Welfare. - 2012. - № 6 (2). - P. 157-167.

11. Cato Varro. On Agriculture / Varro Cato. - Cambridge, MA: Harvard University Press, 1934. - 576 p.

12. Cicero. Tusculan Disputations / Cicero; Rev. ed. - Cambridge, MA: Harvard University Press, $1945 .-624$ p.

13. Davis J. B. The Homo Economicus Conception of the Individual: An Ontological Approach / J. B. Davis; U. Mäki, D. M. Gabbay, P. Thagard, J. Woods editors // Philosophy of Economics. - Amsterdam: North Holland, 2012. - P. 459-482.

14. Gaechter S. Behavioural Economics: From Homo Economicus to Homo Sapiens / S. Gaechter. - London: Routledge, 2016. - 288 p. 
15. Galbraith J. K. The Economics of Innocent Fraud / J. K. Galbraith. - New York: Penguin, 2005. - 64 p.

16. Gaus G. F. The Limits of Homo Economicus: The Conflict of Values and Principles / C. Favor, G. F. Gaus, J. Lamont, editors // Essays on Philosophy, Politics \& Economics: Integration \& Common Research Projects. Stanford: Stanford Economics and Finance, 2010. - P. 37-68.

17. Hamann T. H. Neoliberalism, Governmentality, and Ethics / T. H. Hamann // Foucault Studies. -2009 . - № 6. - P. 37-59.

18. Ivarola L. Incompatibility of Uncertainty in Economics with the Logic of the Homo Economicus and with the Construction of Closed Systems / L. Ivarola // Cinta de Moebio. - 2017. - № 58. - P. 1-12.

19. McMahon J. Behavioral Economics as Neoliberalism: Producing and Governing Homo Economicus / J. McMahon // Contemporary Political Theory. - 2015. - № 14 (2). - P. 137-158.

20. McMurtry J. Behind Global System Collapse: The Life-Blind Structure of Economic Rationality / J. McMurtry // Journal of Business Ethics. - 2012. - № 108 (1). - P. 49-60.

21. Mill J. S. Principles of Political Economy and Chapters on Socialism / J. S. Mill. - New York: Oxford University Press, 2008. -512 p.

22. Read J. A Genealogy of Homo-Economicus: Neoliberalism and the Production of Subjectivity / J. A. Read // Foucault Studies. - 2009. - № 6. - P. 25-36.

23. Weber M. Economy and Society: An Outline of Interpretive Sociology / M. weber; G. Roth, C. Wittich, editors. - Berkeley: University of California Press, 1978. - 1469p.

24. Wilmot B. T. Looking beyond the Individualism \& Homo Economicus of Neoclassical Economics / B. T. Wilmot // Journal of Catholic Social Thought. - 2012. - № 9 (1). - P. 205-208.

\section{REFERENCES}

1. Bentham, J. (1998) Vvedenyje v osnovanija nravstvennosty i zakonodatelstva [An introduction to the principles of morals and legislation]. Moscow: ROSSPEN [in Russian ].

2. Carmin, A.S. (2006) Filosofija kultury v informacionnom obschestve: problemy i perspektivy [The philosophy of culture in the information society: problems and prospects.]. Question of philosophy, 2, 52-61 [in Russian].

3. Mises, L. (2005) Chelovecheskaya dejatelnost: Tractat po ekonomicheskoj teoriji [Human action: a Treatise on economic theory]. Chelyabinsk: Sotsium [in Russian].

4. Milgrom, P., \& Roberts, J. (1999) Ekonomika, organizacija i menedgment [Economics, organization and management.]. Vol 1. Saint-Petersburg: Ekonomicheskaya shkola [in Russian].

5. Petinova, O.B. (2016) Ekonomicheskij chelovek: opyt socialno-filosofskoj eksplikaciji [Economic person: experience of social and philosophical explication]. Odessa: Pechatnyy dom [in Ukranian].

6. Peccei, A. (1985) Chelovecheskiye kachestva [The Human Quality]. Moscow: Progress [in Russian]

7. Smith, A. (2007) Issledovaniye o prirode i prichinah bogatstva narodov [An Inquiry into theNature and Causes of the Wealth of Nations]. Moscow: Eksmo [in Russian].

8. Friedman, M. (1994) Metodologiya pozitivnoj ekonomicheskoj nauki [The Methodology of Positive Economics.]. THESIS, 4, 20-52 [in Russian].

9. Attick, D. (2017). Homo Economicus at School: Neoliberal Education and Teacher as Economic Being. Educational Studies: Journal of the American Educational Studies Association, 53 (1), 37-48.

10. Brecher, B. (2012) The Family and Neoliberalism: Time to Revive a Critique. Ethics and Social Welfare, 6 (2), 157-167.

11. Cato, Varro. (1934) On Agriculture. Cambridge, MA: Harvard University Press.

12. Cicero. (1945) Tusculan Disputations. Rev. ed. Cambridge, MA: Harvard University Press.

13. Davis, J.B. (2012) The Homo Economicus Conception of the Individual: An Ontological Approach. J. B. Davis;

U. Mäki, D. M. Gabbay, P. Thagard, J. Woods (Eds.). Philosophy of Economics. Amsterdam: North Holland.

14. Gaechter, S. (2016) Behavioural Economics: From Homo Economicus to Homo Sapiens. London: Routledge.

15. Galbraith, J.K. (2005) The Economics of Innocent Fraud. New York: Penguin.

16. Gaus, G.F. (2010) The Limits of Homo Economicus: The Conflict of Values and Principles. C. Favor, G. F. Gaus, J. Lamont (Eds.). Essays on Philosophy, Politics \& Economics: Integration \& Common Research Projects. Stanford: Stanford Economics and Finance.

17. Hamann, T.H. (2009) Neoliberalism, Governmentality, and Ethics. Foucault Studies, 6, 37-59.

18. Ivarola, L. (2017) Incompatibility of Uncertainty in Economics with the Logic of the Homo Economicus and with the Construction of Closed Systems. Cinta de Moebio, 58, 1-12.

19. McMahon, J. (2015) Behavioral Economics as Neoliberalism: Producing and Governing Homo Economicus. Contemporary Political Theory, 14 (2), 137-158.

20. McMurtry, J. (2012) Behind Global System Collapse: The Life-Blind Structure of Economic Rationality. Journal of Business Ethics, 108 (1), 49-60. 
21. Mill, J.S. (2008) Principles of Political Economy and Chapters on Socialism. New York: Oxford University Press.

22. Read, J. (2009) A Genealogy of Homo-Economicus: Neoliberalism and the Production of Subjectivity. Foucault Studies, 6, 25-36.

23. Weber, M. (1978) Economy and Society: An Outline of Interpretive Sociology. G. Roth, C. Wittich (Eds.). Berkeley: University of California Press.

24. Wilmot, B.T. (2012) Looking beyond the Individualism \& Homo Economicus of Neoclassical Economics. Journal of Catholic Social Thought, 9 (1), 205-208.

\section{Рудан Наталя Сергіївна}

\section{Аспірант}

Південноукраїнський національний педагогічний університет імені К. Д. Ушинського

65000, м. Одеса, вул. Старопортофранківська, 26

\section{Rudan Natalia}

Post-graduate-student

K. D. Ushynsky South Ukrainian National Pedagogical University

26, Staroportofrankivs`ka St., Odesa, 65000, Ukraine

Email: natasharudan@gmail.com

Цитування: Рудан Н. С. Генезис та еволюційні трансформації економічної культури: соціально-філософський аналіз / Н. С. Руданська // Науково-теоретичний альманах «Грані». - 2018. - Т. 21. - № 3. C. 124-131.

Citation: Rudan, N.S. (2018). Henezys ta evoliutsiini transformatsii ekonomichnoi kultury: sotsialnofilosofskyi analiz [Genesis and evolutionary transformations of economic culture: social- philosophical analysis]. Scientific and theoretical almanac «Grani», 21(3), 124-131. 